\title{
SEMANA BRASILEIRA DE ENFERMAGEM.
}

Para a ABEn, o mês de MAIO tem um significado especial - comemora-se o Dia do Enfermeiro e a Semana Brasileira de Enfermagem, iniciativas pioneiras da entidade. A primeira foi instituida pelo presidente da república Getúlio Vargas, através do Decreto $n^{\circ}$ 2956, de 10 de agosto de 1938. Este decreto determina, inclusive, que na data de 12 de maio as enfermeiras devem "prestar homenagens especiais à memória de Anna Nery em todos os hospitais e escolas de Enfermagem". A segunda nasceu no Rio de Janeiro, na Escola de Enfermagem Anna Nery, idealizada pela sua diretora Lais Netto dos Reys, em 1940, sob a denominação de Semana da Enfermeira. O inicio desta semana deu-se em 12 de maio, para celebrar o nascimento de Florence Nightingale em 1830, e o seu término em 20 de maio, para rememorar o falecimento de Anna Nery em 1880, o que permanece até os dias atuais.

No Documentário da ABEn - 1926/1976, os objetivos propostos por Lais Netto dos Reys, para a semana são assim registrados:

“1) Honrar Florence Nightingale e Anna Nery; 2) estimular as enfermeiras na procura do aperfeiçoamento dos serviços de Enfermagem, recordando as idéias e os ensinamentos daquelas que as precederam na profissão; 3) facilitar o encontro de diretoras de escolas e tornar possivel o contato dessas com autoridades da administração pública, com profissionais do ramo da saúde e com pessoas interessadas nos problemas da Enfermagem".

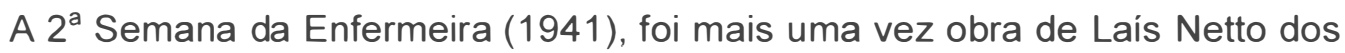
Reys. Estrategicamente, convida as diretoras das escolas de outros estados. Estas compreendendo o significado deste evento para a enfermagem brasileira, iniciam este trabalho em seus estados

Exitosa, a prática da Semana da Enfermeira foi se expandindo por todo território brasileiro e aonde as seções da ABEn foram sendo criadas, tomavam para si o dever de realizá-la com a parceria das Escolas de Enfermagem. Da mesma forma, "outros grupos da equipe de enfermagem começaram também a organizar programas semelhantes nestas datas". 
Após 18 anos (1958), sob o mandato da presidente da ABEn, Marina de Andrade Resende, a assembléia geral da entidade recomendou "a criação, por ato oficial, da Semana de Enfermagem", visando com isso a "união de todos aqueles que formam a equipe de enfermagem e militam nos serviços de saúde". $\mathrm{O}$ ato, ousado à época, tem norteado a realização deste evento e consolidado a idéia de que o caminho da unidade fortalece os interesses da enfermagem.

Enfim, em 12/05/60 (Decreto $n^{\circ}$ 48.202) o presidente da república Juscelino Kubitschek de Oliveira oficializa a Semana de Enfermagem com o objetivo de "promover o congraçamento entre os profissionais de enfermagem, através de encontros cientificos, culturais e sociais".

Nas últimas décadas, a Assembléia Geral de Delegados da ABEn aprova o tema central da semana, em torno do qual as atividades das categorias de enfermagem devem se mobilizar. Preocupações e questões gerais da profissão e dos profissionais, assim como compromisso com a saúde das pessoas e coletividades têm sido temário desses encontros. O envolvimento dos representantes políticos da população com a categoria neste momento tem sido uma oportunidade importante para que, a cada vez, a enfermagem se faça conhecer e a um só tempo garantir o direito das pessoas a uma enfermagem sem riscos.

Todavia, penso que uma estratégia tão poderosa para a unidade dos trabalhadores de enfermagem e da população, ainda não está plenamente explorada. É preciso que os enfermeiros de serviço e docentes exerçam de fato o seu direito de liderar a enfermagem em busca de novos caminhos na defesa da vida das pessoas. Enfim, que façam do temário da Semana da Enfermagem um programa anual a ser desenvolvido por toda a enfermagem brasileira durante $o$ ano inteiro. 